\title{
Nueva especie de Laurinoxylon (Lauraceae) de la Formación El Bosque (Eoceno), Chiapas, México
}

\author{
Diana Karen Pérez-Lara, Emilio Estrada-Ruiz, Carlos Castañeda-Posadas
}

\begin{abstract}
Diana Karen Pérez-Lara
Maestría en Biociencias, Departamento de Zoología, Escuela Nacional de Ciencias Biológicas, Instituto Politécnico Nacional, Prolongación de Carpio y Plan de Ayala s/n, 11340, GDMX, México.
\end{abstract}

\section{Emilio Estrada-Ruiz}

emilkpaleobot@yahoo.com.mx

Departamento de Zoología, Laboratorio de Ecología, Escuela Nacional de Ciencias Biológicas, Instituto Politécnico Nacional, Prolongación de Carpio y Plan de Ayala s/n, 11340 , CDMX, México.

\section{Garlos Castañeda-Posadas}

Benemérita Universidad Autónoma de Puebla, Facultad de Ciencias Biológicas. Laboratorio de Paleontología. Blvd. Valsequillo y Av. San Claudio, Edificio BIO-1, Ciudad Universitaria, Col. Jardines de San Manuel, C.P. 72570 Puebla, México.
BOL. SOC. GEOL. MEX. 2019

VOL. 71 NO. 3

P. $761-772$

http://dx.doi.org/10.18268/BSGM2019v7 ln3a8

\section{RESUMEN}

Se describe una nueva especie del género-fósil Laurinoxylon procedente de la Formación El Bosque (Eoceno), Chiapas, México. La nueva especie presenta las siguientes características distintivas: porosidad difusa, vasos solitarios y en múltiples radiales, placas de perforación simple, punteaduras intervasculares alternas, punteaduras vaso-radio con bordes reducidos de forma redonda, alargadas horizontal, vertical y diagonalmente, tílides con forma de burbuja, parénquima axial paratraqueal, vasicéntrico y apotraqueal difuso, radios heterocelulares y células oleíferas asociadas a los radios y entre las fibras. Este género-fósil ha sido descrito desde el Cretácico hasta el Neógeno en varias partes del mundo. En México, se reporta formalmente por vez primera la presencia de Laurinoxylon, además de ser el primer reporte de macrofósil de Lauraceae para el Eoceno de nuestro país. Esta nueva especie soporta aún más la teoría que Lauraceae tuvo una amplia distribución durante el pasado y que México pudo ser un lugar importante de diversificación de la familia como lo demuestra su registro fósil que proviene desde el Cretácico Superior y por su número de géneros y especies que actualmente crecen.

Palabras clave: Eoceno, Laurinoxylon, Formación El Bosque, Ghiapas, México, madera fósil.

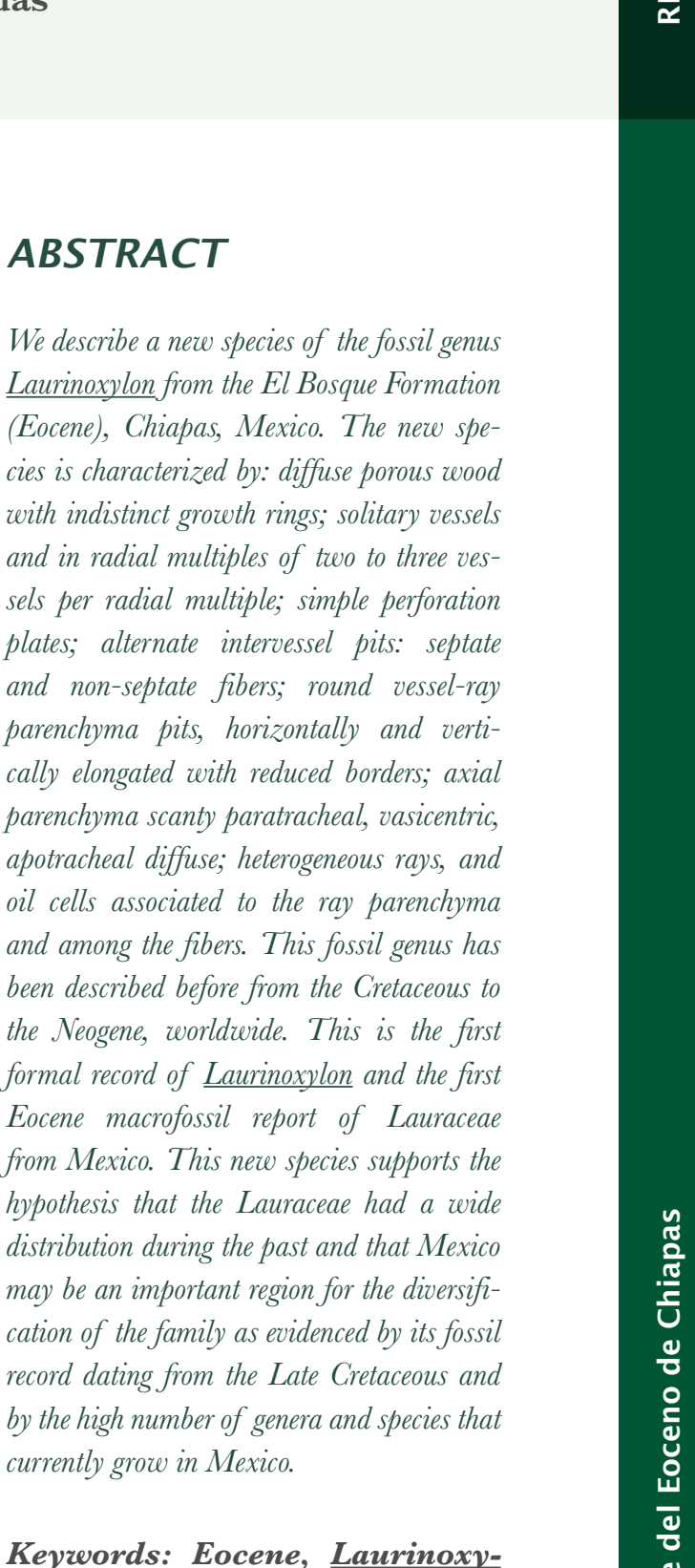

ABSTRACT
We describe a new species of the fossil genus
Laurinoxylon from the El Bosque Formation
(Eocene), Chiapas, Mexico. The new spe-
cies is characterized by: diffuse porous wood
with indistinct growth rings; solitary vessels
and in radial multiples of two to three ves-
sels per radial multiple; simple perforation
plates; alternate intervessel pits: septate
and non-septate fibers; round vessel-ray
parenchyma pits, horizontally and verti-
cally elongated with reduced borders; axial
parenchyma scanty paratracheal, vasicentric,
apotracheal diffuse; heterogeneous rays, and
oil cells associated to the ray parenchyma
and among the fibers. This fossil genus has
been described before from the Cretaceous to
the Neogene, worldwide. This is the first
formal record of Laurinoxylon and the first
Eocene macrofossil report of Lauraceae
from Mexico. This new species supports the
hypothesis that the Lauraceae had a wide
distribution during the past and that Mexico
may be an important region for the diversifi-
cation of the family as evidenced by its fossil
record dating from the Late Cretaceous and
by the high number of genera and species that
currently grow in Mexico.
Keyzwords: Eocene, Laurinoxy-
a

ABSTRACT
We describe a new species of the fossil genus
Laurinoxylon from the El Bosque Formation
(Eocene), Chiapas, Mexico. The new spe-
cies is characterized by: diffuse porous wood
weith indistinct growth rings; solitary vessels
and in radial multiples of two to three ves-
sels per radial multiple; simple perforation
plates; alternate intervessel pits: septate
and non-septate fibers; round vessel-ray
parenchyma pits, horizontally and verti-
cally elongated with reduced borders; axial
parenchyma scanty paratracheal, vasicentric,
apotracheal diffuse; heterogeneous rays, and
oil cells associated to the ray parenchyma
and among the fibers. This fossil genus has
been described before from the Cretaceous to
the Neogene, worldwide. This is the first
formal record of Laurinoxylon and the first
Eocene macrofossil report of Lauraceae
from Mexico. This new species supports the
hypothesis that the Lauraceae had a wide
distribution during the past and that Mexico
may be an important region for the diversifi-
cation of the family as evidenced by its fossil
record dating from the Late Cretaceous and
by the high number of genera and species that
currently grow in Mexico.
Keyzwords: Eocene, Laurinoxy-
a

ABSTRACT
We describe a new species of the fossil genus
Laurinoxylon from the El Bosque Formation
(Eocene), Chiapas, Mexico. The new spe-
cies is characterized by: diffuse porous wood
with indistinct growth rings; solitary vessels
and in radial multiples of two to three ves-
sels per radial multiple; simple perforation
plates; alternate intervessel pits: septate
and non-septate fibers; round vessel-ray
parenchyma pits, horizontally and verti-
cally elongated with reduced borders; axial
parenchyma scanty paratracheal, vasicentric,
apotracheal diffuse; heterogeneous rays, and
oil cells associated to the ray parenchyma
and among the fibers. This fossil genus has
been described before from the Cretaceous to
the Neogene, worldwide. This is the first
formal record of Laurinoxylon and the first
Eocene macrofossil report of Lauraceae
from Mexico. This new species supports the
hypothesis that the Lauraceae had a wide
distribution during the past and that Mexico
may be an important region for the diversifi-
cation of the family as evidenced by its fossil
record dating from the Late Cretaceous and
by the high number of genera and species that
currently grow in Mexico.
Keyzwords: Eocene, Laurinoxy-
a

ABSTRACT
We describe a new species of the fossil genus
Laurinoxylon from the El Bosque Formation
(Eocene), Chiapas, Mexico. The new spe-
cies is characterized by: diffuse porous wood
with indistinct growth rings; solitary vessels
and in radial multiples of two to three ves-
sels per radial multiple; simple perforation
plates; alternate intervessel pits: septate
and non-septate fibers; round vessel-ray
parenchyma pits, horizontally and verti-
cally elongated with reduced borders; axial
parenchyma scanty paratracheal, vasicentric,
apotracheal diffuse; heterogeneous rays, and
oil cells associated to the ray parenchyma
and among the fibers. This fossil genus has
been described before from the Cretaceous to
the Neogene, worldwide. This is the first
formal record of Laurinoxylon and the first
Eocene macrofossil report of Lauraceae
from Mexico. This new species supports the
hypothesis that the Lauraceae had a wide
distribution during the past and that Mexico
may be an important region for the diversifi-
cation of the family as evidenced by its fossil
record dating from the Late Cretaceous and
by the high number of genera and species that
currently grow in Mexico.
Keyzwords: Eocene, Laurinoxy-
a

ABSTRACT
We describe a new species of the fossil genus
Laurinoxylon from the El Bosque Formation
(Eocene), Chiapas, Mexico. The new spe-
cies is characterized by: diffuse porous wood
with indistinct growth rings; solitary vessels
and in radial multiples of two to three ves-
sels per radial multiple; simple perforation
plates; alternate intervessel pits: septate
and non-septate fibers; round vessel-ray
parenchyma pits, horizontally and verti-
cally elongated with reduced borders; axial
parenchyma scanty paratracheal, vasicentric,
apotracheal diffuse; heterogeneous rays, and
oil cells associated to the ray parenchyma
and among the fibers. This fossil genus has
been described before from the Cretaceous to
the Neogene, worldwide. This is the first
formal record of Laurinoxylon and the first
Eocene macrofossil report of Lauraceae
from Mexico. This new species supports the
hypothesis that the Lauraceae had a wide
distribution during the past and that Mexico
may be an important region for the diversifi-
cation of the family as evidenced by its fossil
record dating from the Late Cretaceous and
by the high number of genera and species that
currently grow in Mexico.
Keyzwords: Eocene, Laurinoxy-
a

ABSTRACT
We describe a new species of the fossil genus
Laurinoxylon from the El Bosque Formation
(Eocene), Chiapas, Mexico. The new spe-
cies is characterized by: diffuse porous wood
with indistinct growth rings; solitary vessels
and in radial multiples of two to three ves-
sels per radial multiple; simple perforation
plates; alternate intervessel pits: septate
and non-septate fibers; round vessel-ray
parenchyma pits, horizontally and verti-
cally elongated with reduced borders; axial
parenchyma scanty paratracheal, vasicentric,
apotracheal diffuse; heterogeneous rays, and
oil cells associated to the ray parenchyma
and among the fibers. This fossil genus has
been described before from the Cretaceous to
the Neogene, worldwide. This is the first
formal record of Laurinoxylon and the first
Eocene macrofossil report of Lauraceae
from Mexico. This new species supports the
hypothesis that the Lauraceae had a wide
distribution during the past and that Mexico
may be an important region for the diversifi-
cation of the family as evidenced by its fossil
record dating from the Late Cretaceous and
by the high number of genera and species that
currently grow in Mexico.
Keyzwords: Eocene, Laurinoxy-
a

ABSTRACT
We describe a new species of the fossil genus
Laurinoxylon from the El Bosque Formation
(Eocene), Chiapas, Mexico. The new spe-
cies is characterized by: diffuse porous wood
with indistinct growth rings; solitary vessels
and in radial multiples of two to three ves-
sels per radial multiple; simple perforation
plates; alternate intervessel pits: septate
and non-septate fibers; round vessel-ray
parenchyma pits, horizontally and verti-
cally elongated with reduced borders; axial
parenchyma scanty paratracheal, vasicentric,
apotracheal diffuse; heterogeneous rays, and
oil cells associated to the ray parenchyma
and among the fibers. This fossil genus has
been described before from the Cretaceous to
the Neogene, worldwide. This is the first
formal record of Laurinoxylon and the first
Eocene macrofossil report of Lauraceae
from Mexico. This new species supports the
hypothesis that the Lauraceae had a wide
distribution during the past and that Mexico
may be an important region for the diversifi-
cation of the family as evidenced by its fossil
record dating from the Late Cretaceous and
by the high number of genera and species that
currently grow in Mexico.
Keyzwords: Eocene, Laurinoxy-
a

ABSTRACT
We describe a new species of the fossil genus
Laurinoxylon from the El Bosque Formation
(Eocene), Chiapas, Mexico. The new spe-
cies is characterized by: diffuse porous wood
weith indistinct growth rings; solitary vessels
and in radial multiples of two to three ves-
sels per radial multiple; simple perforation
plates; alternate intervessel pits: septate
and non-septate fibers; round vessel-ray
parenchyma pits, horizontally and verti-
cally elongated with reduced borders; axial
parenchyma scanty paratracheal, vasicentric,
apotracheal diffuse; heterogeneous rays, and
oil cells associated to the ray parenchyma
and among the fibers. This fossil genus has
been described before from the Cretaceous to
the Neogene, worldwide. This is the first
formal record of Laurinoxylon and the first
Eocene macrofossil report of Lauraceae
from Mexico. This new species supports the
hypothesis that the Lauraceae had a wide
distribution during the past and that Mexico
may be an important region for the diversifi-
cation of the family as evidenced by its fossil
record dating from the Late Cretaceous and
by the high number of genera and species that
currently grow in Mexico.
Keyzeords: Eocene, Laurinoxy-
a

ABSTRACT
We describe a new species of the fossil genus
Laurinoxylon from the El Bosque Formation
(Eocene), Chiapas, Mexico. The new spe-
cies is characterized by: diffuse porous wood
weith indistinct growth rings; solitary vessels
and in radial multiples of two to three ves-
sels per radial multiple; simple perforation
plates; alternate intervessel pits: septate
and non-septate fibers; round vessel-ray
parenchyma pits, horizontally and verti-
cally elongated with reduced borders; axial
parenchyma scanty paratracheal, vasicentric,
apotracheal diffuse; heterogeneous rays, and
oil cells associated to the ray parenchyma
and among the fibers. This fossil genus has
been described before from the Cretaceous to
the Neogene, worldwide. This is the first
formal record of Laurinoxylon and the first
Eocene macrofossil report of Lauraceae
from Mexico. This new species supports the
hypothesis that the Lauraceae had a wide
distribution during the past and that Mexico
may be an important region for the diversifi-
cation of the family as evidenced by its fossil
record dating from the Late Cretaceous and
by the high number of genera and species that
currently grow in Mexico.
Keyzeords: Eocene, Laurinoxy-
a

ABSTRACT
We describe a new species of the fossil genus
Laurinoxylon from the El Bosque Formation
(Eocene), Chiapas, Mexico. The new spe-
cies is characterized by: diffuse porous wood
weith indistinct growth rings; solitary vessels
and in radial multiples of two to three ves-
sels per radial multiple; simple perforation
plates; alternate intervessel pits: septate
and non-septate fibers; round vessel-ray
parenchyma pits, horizontally and verti-
cally elongated with reduced borders; axial
parenchyma scanty paratracheal, vasicentric,
apotracheal diffuse; heterogeneous rays, and
oil cells associated to the ray parenchyma
and among the fibers. This fossil genus has
been described before from the Cretaceous to
the Neogene, worldwide. This is the first
formal record of Laurinoxylon and the first
Eocene macrofossil report of Lauraceae
from Mexico. This new species supports the
hypothesis that the Lauraceae had a wide
distribution during the past and that Mexico
may be an important region for the diversifi-
cation of the family as evidenced by its fossil
record dating from the Late Cretaceous and
by the high number of genera and species that
currently grow in Mexico.
Keyzeords: Eocene, Laurinoxy-
a

ABSTRACT
We describe a new species of the fossil genus
Laurinoxylon from the El Bosque Formation
(Eocene), Chiapas, Mexico. The new spe-
cies is characterized by: diffuse porous wood
weith indistinct growth rings; solitary vessels
and in radial multiples of two to three ves-
sels per radial multiple; simple perforation
plates; alternate intervessel pits: septate
and non-septate fibers; round vessel-ray
parenchyma pits, horizontally and verti-
cally elongated with reduced borders; axial
parenchyma scanty paratracheal, vasicentric,
apotracheal diffuse; heterogeneous rays, and
oil cells associated to the ray parenchyma
and among the fibers. This fossil genus has
been described before from the Cretaceous to
the Neogene, worldwide. This is the first
formal record of Laurinoxylon and the first
Eocene macrofossil report of Lauraceae
from Mexico. This new species supports the
hypothesis that the Lauraceae had a wide
distribution during the past and that Mexico
may be an important region for the diversifi-
cation of the family as evidenced by its fossil
record dating from the Late Cretaceous and
by the high number of genera and species that
currently grow in Mexico.
Keyzeords: Eocene, Laurinoxy-
a

ABSTRACT
We describe a new species of the fossil genus
Laurinoxylon from the El Bosque Formation
(Eocene), Chiapas, Mexico. The new spe-
cies is characterized by: diffuse porous wood
weith indistinct growth rings; solitary vessels
and in radial multiples of two to three ves-
sels per radial multiple; simple perforation
plates; alternate intervessel pits: septate
and non-septate fibers; round vessel-ray
parenchyma pits, horizontally and verti-
cally elongated with reduced borders; axial
parenchyma scanty paratracheal, vasicentric,
apotracheal diffuse; heterogeneous rays, and
oil cells associated to the ray parenchyma
and among the fibers. This fossil genus has
been described before from the Cretaceous to
the Neogene, worldwide. This is the first
formal record of Laurinoxylon and the first
Eocene macrofossil report of Lauraceae
from Mexico. This new species supports the
hypothesis that the Lauraceae had a wide
distribution during the past and that Mexico
may be an important region for the diversifi-
cation of the family as evidenced by its fossil
record dating from the Late Cretaceous and
by the high number of genera and species that
currently grow in Mexico.
Keyzeords: Eocene, Laurinoxy-
a

ABSTRACT
We describe a new species of the fossil genus
Laurinoxylon from the El Bosque Formation
(Eocene), Chiapas, Mexico. The new spe-
cies is characterized by: diffuse porous wood
weith indistinct growth rings; solitary vessels
and in radial multiples of two to three ves-
sels per radial multiple; simple perforation
plates; alternate intervessel pits: septate
and non-septate fibers; round vessel-ray
parenchyma pits, horizontally and verti-
cally elongated with reduced borders; axial
parenchyma scanty paratracheal, vasicentric,
apotracheal diffuse; heterogeneous rays, and
oil cells associated to the ray parenchyma
and among the fibers. This fossil genus has
been described before from the Cretaceous to
the Neogene, worldwide. This is the first
formal record of Laurinoxylon and the first
Eocene macrofossil report of Lauraceae
from Mexico. This new species supports the
hypothesis that the Lauraceae had a wide
distribution during the past and that Mexico
may be an important region for the diversifi-
cation of the family as evidenced by its fossil
record dating from the Late Cretaceous and
by the high number of genera and species that
currently grow in Mexico.
Keyzeords: Eocene, Laurinoxy-
a

ABSTRACT
We describe a new species of the fossil genus
Laurinoxylon from the El Bosque Formation
(Eocene), Chiapas, Mexico. The new spe-
cies is characterized by: diffuse porous wood
weith indistinct growth rings; solitary vessels
and in radial multiples of two to three ves-
sels per radial multiple; simple perforation
plates; alternate intervessel pits: septate
and non-septate fibers; round vessel-ray
parenchyma pits, horizontally and verti-
cally elongated with reduced borders; axial
parenchyma scanty paratracheal, vasicentric,
apotracheal diffuse; heterogeneous rays, and
oil cells associated to the ray parenchyma
and among the fibers. This fossil genus has
been described before from the Cretaceous to
the Neogene, worldwide. This is the first
formal record of Laurinoxylon and the first
Eocene macrofossil report of Lauraceae
from Mexico. This new species supports the
hypothesis that the Lauraceae had a wide
distribution during the past and that Mexico
may be an important region for the diversifi-
cation of the family as evidenced by its fossil
record dating from the Late Cretaceous and
by the high number of genera and species that
currently grow in Mexico.
Keyzwords: Eocene, Laurinoxy-
a

ABSTRACT
We describe a new species of the fossil genus
Laurinoxylon from the El Bosque Formation
(Eocene), Chiapas, Mexico. The new spe-
cies is characterized by: diffuse porous wood
weith indistinct growth rings; solitary vessels
and in radial multiples of two to three ves-
sels per radial multiple; simple perforation
plates; alternate intervessel pits: septate
and non-septate fibers; round vessel-ray
parenchyma pits, horizontally and verti-
cally elongated with reduced borders; axial
parenchyma scanty paratracheal, vasicentric,
apotracheal diffuse; heterogeneous rays, and
oil cells associated to the ray parenchyma
and among the fibers. This fossil genus has
been described before from the Cretaceous to
the Neogene, worldwide. This is the first
formal record of Laurinoxylon and the first
Eocene macrofossil report of Lauraceae
from Mexico. This new species supports the
hypothesis that the Lauraceae had a wide
distribution during the past and that Mexico
may be an important region for the diversifi-
cation of the family as evidenced by its fossil
record dating from the Late Cretaceous and
by the high number of genera and species that
currently grow in Mexico.
Keyzwords: Eocene, Laurinoxy-
a

ABSTRACT
We describe a new species of the fossil genus
Laurinoxylon from the El Bosque Formation
(Eocene), Chiapas, Mexico. The new spe-
cies is characterized by: diffuse porous wood
weith indistinct growth rings; solitary vessels
and in radial multiples of two to three ves-
sels per radial multiple; simple perforation
plates; alternate intervessel pits: septate
and non-septate fibers; round vessel-ray
parenchyma pits, horizontally and verti-
cally elongated with reduced borders; axial
parenchyma scanty paratracheal, vasicentric,
apotracheal diffuse; heterogeneous rays, and
oil cells associated to the ray parenchyma
and among the fibers. This fossil genus has
been described before from the Cretaceous to
the Neogene, worldwide. This is the first
formal record of Laurinoxylon and the first
Eocene macrofossil report of Lauraceae
from Mexico. This new species supports the
hypothesis that the Lauraceae had a wide
distribution during the past and that Mexico
may be an important region for the diversifi-
cation of the family as evidenced by its fossil
record dating from the Late Cretaceous and
by the high number of genera and species that
currently grow in Mexico.
Keyzwords: Eocene, Laurinoxy-
a

ABSTRACT
We describe a new species of the fossil genus
Laurinoxylon from the El Bosque Formation
(Eocene), Chiapas, Mexico. The new spe-
cies is characterized by: diffuse porous wood
weith indistinct growth rings; solitary vessels
and in radial multiples of two to three ves-
sels per radial multiple; simple perforation
plates; alternate intervessel pits: septate
and non-septate fibers; round vessel-ray
parenchyma pits, horizontally and verti-
cally elongated with reduced borders; axial
parenchyma scanty paratracheal, vasicentric,
apotracheal diffuse; heterogeneous rays, and
oil cells associated to the ray parenchyma
and among the fibers. This fossil genus has
been described before from the Cretaceous to
the Neogene, worldwide. This is the first
formal record of Laurinoxylon and the first
Eocene macrofossil report of Lauraceae
from Mexico. This new species supports the
hypothesis that the Lauraceae had a wide
distribution during the past and that Mexico
may be an important region for the diversifi-
cation of the family as evidenced by its fossil
record dating from the Late Cretaceous and
by the high number of genera and species that
currently grow in Mexico.
Keyzwords: Eocene, Laurinoxy-
a

ABSTRACT
We describe a new species of the fossil genus
Laurinoxylon from the El Bosque Formation
(Eocene), Chiapas, Mexico. The new spe-
cies is characterized by: diffuse porous wood
weith indistinct growth rings; solitary vessels
and in radial multiples of two to three ves-
sels per radial multiple; simple perforation
plates; alternate intervessel pits: septate
and non-septate fibers; round vessel-ray
parenchyma pits, horizontally and verti-
cally elongated with reduced borders; axial
parenchyma scanty paratracheal, vasicentric,
apotracheal diffuse; heterogeneous rays, and
oil cells associated to the ray parenchyma
and among the fibers. This fossil genus has
been described before from the Cretaceous to
the Neogene, worldwide. This is the first
formal record of Laurinoxylon and the first
Eocene macrofossil report of Lauraceae
from Mexico. This new species supports the
hypothesis that the Lauraceae had a wide
distribution during the past and that Mexico
may be an important region for the diversifi-
cation of the family as evidenced by its fossil
record dating from the Late Cretaceous and
by the high number of genera and species that
currently grow in Mexico.
Keyzwords: Eocene, Laurinoxy-
a

ABSTRACT
We describe a new species of the fossil genus
Laurinoxylon from the El Bosque Formation
(Eocene), Chiapas, Mexico. The new spe-
cies is characterized by: diffuse porous wood
weith indistinct growth rings; solitary vessels
and in radial multiples of two to three ves-
sels per radial multiple; simple perforation
plates; alternate intervessel pits: septate
and non-septate fibers; round vessel-ray
parenchyma pits, horizontally and verti-
cally elongated with reduced borders; axial
parenchyma scanty paratracheal, vasicentric,
apotracheal diffuse; heterogeneous rays, and
oil cells associated to the ray parenchyma
and among the fibers. This fossil genus has
been described before from the Cretaceous to
the Neogene, worldwide. This is the first
formal record of Laurinoxylon and the first
Eocene macrofossil report of Lauraceae
from Mexico. This new species supports the
hypothesis that the Lauraceae had a wide
distribution during the past and that Mexico
may be an important region for the diversifi-
cation of the family as evidenced by its fossil
record dating from the Late Cretaceous and
by the high number of genera and species that
currently grow in Mexico.
Keyzeords: Eocene, Laurinoxy-
a

ABSTRACT
We describe a new species of the fossil genus
Laurinoxylon from the El Bosque Formation
(Eocene), Chiapas, Mexico. The new spe-
cies is characterized by: diffuse porous wood
weith indistinct growth rings; solitary vessels
and in radial multiples of two to three ves-
sels per radial multiple; simple perforation
plates; alternate intervessel pits: septate
and non-septate fibers; round vessel-ray
parenchyma pits, horizontally and verti-
cally elongated with reduced borders; axial
parenchyma scanty paratracheal, vasicentric,
apotracheal diffuse; heterogeneous rays, and
oil cells associated to the ray parenchyma
and among the fibers. This fossil genus has
been described before from the Cretaceous to
the Neogene, worldwide. This is the first
formal record of Laurinoxylon and the first
Eocene macrofossil report of Lauraceae
from Mexico. This new species supports the
hypothesis that the Lauraceae had a wide
distribution during the past and that Mexico
may be an important region for the diversifi-
cation of the family as evidenced by its fossil
record dating from the Late Cretaceous and
by the high number of genera and species that
currently grow in Mexico.
Keyzwords: Eocene, Laurinoxy-
a

ABSTRACT
We describe a new species of the fossil genus
Laurinoxylon from the El Bosque Formation
(Eocene), Chiapas, Mexico. The new spe-
cies is characterized by: diffuse porous wood
weith indistinct growth rings; solitary vessels
and in radial multiples of two to three ves-
sels per radial multiple; simple perforation
plates; alternate intervessel pits: septate
and non-septate fibers; round vessel-ray
parenchyma pits, horizontally and verti-
cally elongated with reduced borders; axial
parenchyma scanty paratracheal, vasicentric,
apotracheal diffuse; heterogeneous rays, and
oil cells associated to the ray parenchyma
and among the fibers. This fossil genus has
been described before from the Cretaceous to
the Neogene, worldwide. This is the first
formal record of Laurinoxylon and the first
Eocene macrofossil report of Lauraceae
from Mexico. This new species supports the
hypothesis that the Lauraceae had a wide
distribution during the past and that Mexico
may be an important region for the diversifi-
cation of the family as evidenced by its fossil
record dating from the Late Cretaceous and
by the high number of genera and species that
currently grow in Mexico.
Keyzwords: Eocene, Laurinoxy-
a

ABSTRACT
We describe a new species of the fossil genus
Laurinoxylon from the El Bosque Formation
(Eocene), Chiapas, Mexico. The new spe-
cies is characterized by: diffuse porous wood
weith indistinct growth rings; solitary vessels
and in radial multiples of two to three ves-
sels per radial multiple; simple perforation
plates; alternate intervessel pits: septate
and non-septate fibers; round vessel-ray
parenchyma pits, horizontally and verti-
cally elongated with reduced borders; axial
parenchyma scanty paratracheal, vasicentric,
apotracheal diffuse; heterogeneous rays, and
oil cells associated to the ray parenchyma
and among the fibers. This fossil genus has
been described before from the Cretaceous to
the Neogene, worldwide. This is the first
formal record of Laurinoxylon and the first
Eocene macrofossil report of Lauraceae
from Mexico. This new species supports the
hypothesis that the Lauraceae had a wide
distribution during the past and that Mexico
may be an important region for the diversifi-
cation of the family as evidenced by its fossil
record dating from the Late Cretaceous and
by the high number of genera and species that
currently grow in Mexico.
Keyzeords: Eocene, Laurinoxy-
a

ABSTRACT
We describe a new species of the fossil genus
Laurinoxylon from the El Bosque Formation
(Eocene), Chiapas, Mexico. The new spe-
cies is characterized by: diffuse porous wood
weith indistinct growth rings; solitary vessels
and in radial multiples of two to three ves-
sels per radial multiple; simple perforation
plates; alternate intervessel pits: septate
and non-septate fibers; round vessel-ray
parenchyma pits, horizontally and verti-
cally elongated with reduced borders; axial
parenchyma scanty paratracheal, vasicentric,
apotracheal diffuse; heterogeneous rays, and
oil cells associated to the ray parenchyma
and among the fibers. This fossil genus has
been described before from the Cretaceous to
the Neogene, worldwide. This is the first
formal record of Laurinoxylon and the first
Eocene macrofossil report of Lauraceae
from Mexico. This new species supports the
hypothesis that the Lauraceae had a wide
distribution during the past and that Mexico
may be an important region for the diversifi-
cation of the family as evidenced by its fossil
record dating from the Late Cretaceous and
by the high number of genera and species that
currently grow in Mexico.
Keyzeords: Eocene, Laurinoxy-
a

ABSTRACT
We describe a new species of the fossil genus
Laurinoxylon from the El Bosque Formation
(Eocene), Chiapas, Mexico. The new spe-
cies is characterized by: diffuse porous wood
weith indistinct growth rings; solitary vessels
and in radial multiples of two to three ves-
sels per radial multiple; simple perforation
plates; alternate intervessel pits: septate
and non-septate fibers; round vessel-ray
parenchyma pits, horizontally and verti-
cally elongated with reduced borders; axial
parenchyma scanty paratracheal, vasicentric,
apotracheal diffuse; heterogeneous rays, and
oil cells associated to the ray parenchyma
and among the fibers. This fossil genus has
been described before from the Cretaceous to
the Neogene, worldwide. This is the first
formal record of Laurinoxylon and the first
Eocene macrofossil report of Lauraceae
from Mexico. This new species supports the
hypothesis that the Lauraceae had a wide
distribution during the past and that Mexico
may be an important region for the diversifi-
cation of the family as evidenced by its fossil
record dating from the Late Cretaceous and
by the high number of genera and species that
currently grow in Mexico.
Keyzeords: Eocene, Laurinoxy-
a

ABSTRACT
We describe a new species of the fossil genus
Laurinoxylon from the El Bosque Formation
(Eocene), Chiapas, Mexico. The new spe-
cies is characterized by: diffuse porous wood
weith indistinct growth rings; solitary vessels
and in radial multiples of two to three ves-
sels per radial multiple; simple perforation
plates; alternate intervessel pits: septate
and non-septate fibers; round vessel-ray
parenchyma pits, horizontally and verti-
cally elongated with reduced borders; axial
parenchyma scanty paratracheal, vasicentric,
apotracheal diffuse; heterogeneous rays, and
oil cells associated to the ray parenchyma
and among the fibers. This fossil genus has
been described before from the Cretaceous to
the Neogene, worldwide. This is the first
formal record of Laurinoxylon and the first
Eocene macrofossil report of Lauraceae
from Mexico. This new species supports the
hypothesis that the Lauraceae had a wide
distribution during the past and that Mexico
may be an important region for the diversifi-
cation of the family as evidenced by its fossil
record dating from the Late Cretaceous and
by the high number of genera and species that
currently grow in Mexico.
Keyzeords: Eocene, Laurinoxy-
a

ABSTRACT
We describe a new species of the fossil genus
Laurinoxylon from the El Bosque Formation
(Eocene), Chiapas, Mexico. The new spe-
cies is characterized by: diffuse porous wood
weith indistinct growth rings; solitary vessels
and in radial multiples of two to three ves-
sels per radial multiple; simple perforation
plates; alternate intervessel pits: septate
and non-septate fibers; round vessel-ray
parenchyma pits, horizontally and verti-
cally elongated with reduced borders; axial
parenchyma scanty paratracheal, vasicentric,
apotracheal diffuse; heterogeneous rays, and
oil cells associated to the ray parenchyma
and among the fibers. This fossil genus has
been described before from the Cretaceous to
the Neogene, worldwide. This is the first
formal record of Laurinoxylon and the first
Eocene macrofossil report of Lauraceae
from Mexico. This new species supports the
hypothesis that the Lauraceae had a wide
distribution during the past and that Mexico
may be an important region for the diversifi-
cation of the family as evidenced by its fossil
record dating from the Late Cretaceous and
by the high number of genera and species that
currently grow in Mexico.
Keyzwords: Eocene, Laurinoxy-
a

ABSTRACT
We describe a new species of the fossil genus
Laurinoxylon from the El Bosque Formation
(Eocene), Chiapas, Mexico. The new spe-
cies is characterized by: diffuse porous wood
weith indistinct growth rings; solitary vessels
and in radial multiples of two to three ves-
sels per radial multiple; simple perforation
plates; alternate intervessel pits: septate
and non-septate fibers; round vessel-ray
parenchyma pits, horizontally and verti-
cally elongated with reduced borders; axial
parenchyma scanty paratracheal, vasicentric,
apotracheal diffuse; heterogeneous rays, and
oil cells associated to the ray parenchyma
and among the fibers. This fossil genus has
been described before from the Cretaceous to
the Neogene, worldwide. This is the first
formal record of Laurinoxylon and the first
Eocene macrofossil report of Lauraceae
from Mexico. This new species supports the
hypothesis that the Lauraceae had a wide
distribution during the past and that Mexico
may be an important region for the diversifi-
cation of the family as evidenced by its fossil
record dating from the Late Cretaceous and
by the high number of genera and species that
currently grow in Mexico.
Keyzwords: Eocene, Laurinoxy-
a

Keywords: Eocene, Laurinoxylon, El Bosque Formation, Chiapas, Mexico, fossil wood. 


\section{Introducción}

La familia Lauraceae se encuentra ampliamente distribuida alrededor del mundo en regiones tropicales, subtropicales y con algunas especies de zonas templadas; está conformada principalmente por árboles y arbustos, se han descrito entre 45-50 géneros con alrededor de 2500 a 2600 especies (Rohwer, 1993; Johansson, 2013). En México, se reporta la presencia de 10 géneros con 120 especies (Lorea-Hernández, 2002). Algunos géneros encontrados en México son de importancia económica como los frutos de Persea (aguacate) o las hojas del género Litsea, conocidas como hojas de laurel que se usan como condimento para la preparación de alimentos (van der Werff, 1997).

Sobre el registro fósil de Lauraceae, éste es muy amplio e incluye hojas, maderas, polen, frutos, semillas y flores que van desde el Cretácico Tardío hasta el Neógeno Tardío (e.g., Drinnan et al., 1990; Upchurch y Dilcher, 1990; von Balthazar et al., 2007; Estrada-Ruiz et al., 2010). En México, se han recolectado maderas y hojas de Lauraceae en sedimentos del Cretácico Superior de las formaciones Olmos y San Carlos en el norte de México; así como dos registros de maderas del Mioceno de Tlaxcala y Chiapas (e.g., Weber, 1978; CastañedaPosadas et al., 2009; Estrada-Ruiz et al., 2010; García Hernández et al., 2016). Respecto al registro fósil con base en maderas de Lauraceae, se han recolectado prácticamente en todos los continentes, incluyendo la Antárctica (Poole et al., 2000). La abundancia de esta familia en el registro fósil es debido a que la madera de Lauraceae es fácilmente reconocible por la presencia de idioblastos (Wheeler y Manchester, 2002). Se han descrito alrededor de 13 géneros-fósiles, siendo uno de los más importantes por su abundancia y distribución Laurinoxylon, de éste se han reportado alrededor de 90 especies principalmente en Europa y Asia (Gregory et al., 2009).

Laurinoxylon es un género-fósil que presenta una combinación de caracteres a los encontrados en Lauraceae, pero el mosaico de características que presenta no se ha podido asignar a un género actual (Mantzouka et al., 2016). Respecto a la diagnosis de este género-fósil, fue enmendado por Dupéron et al. (2008) de la siguiente manera: "maderas fósiles de dicotiledóneas con diámetros de los vasos que van de 100 a $200 \mu \mathrm{m}$, vasos solitarios o en múltiples radiales; placas de perforación simples y algunas veces escalariformes; punteaduras intervasculares alternas y moderadamente largas; tílides presente; parénquima paratraqueal; radios de 1-5 células de ancho, ligeramente heterocelulares y menores a $1 \mathrm{~mm}$ de alto; punteaduras vaso-radio largas, a veces estiradas; fibras libriformes o con punteaduras en la pared; células oleíferas o mucilaginosas (idioblastos) presentes". Posteriormente, Mantzuoka et al. (2016) limitan aún más las características observables dentro de Laurinoxylon y excluyen aquellas especies que en su xilema secundario presentan placas de perforación exclusivamente escalariformes, punteaduras intervasculares de tipo escalariforme, bandas de parénquima marginal o concéntrico, radios predominantemente homocelulares, idioblastos asociados únicamente a los radios, parénquima aliforme o confluente, porosidad circular y radios con una altura mayor a $1 \mathrm{~mm}$ debido a que varias de esos caracteres no se encuentran en Lauraceae o en particular en la diagnosis de Laurinoxylon.

En sedimentos de la Formación El Bosque se han recolectado varias maderas eocénicas de angiospermas (core angiosperms), donde se describe el primer registro formal para México del género-fósil Laurinoxylon. Este nuevo reporte de Lauraceae soporta aún más la teoría que durante el Cenozoico la familia Lauraceae tuvo una amplia distribución a lo largo del país, y que México pudo ser un lugar importante de diversificación de la familia como lo demuestra su registro fósil que proviene desde el Cretácico Superior.

\section{Marco geológico}

La madera fósil se recolectó en un afloramiento que pertenece a la Formación El Bosque. La localidad es conocida como "Las maderas Acala", ubicada a $10 \mathrm{~km}$ al sureste del municipio de Acala, Chiapas, siguiendo la carretera 101, entre las coordenadas 
$92^{\circ} 43^{\prime} 47^{\prime \prime} \mathrm{N}$ y $16^{\circ} 30^{\prime} 41^{\prime \prime} \mathrm{O}$ (Figura 1). Los sedimentos de la Formación El Bosque se componen de una secuencia de aproximadamente 37 metros de limolitas, lutitas, areniscas (Figura 2) y en ocasiones conglomerados polimícticos (JuárezHernández, 2014). En esta formación geológica se han encontrado una diversidad de fósiles representados por invertebrados marinos como son gasterópodos, bivalvos y equinodermos; vertebrados (vertebras de tiburones, tortugas); algas calcáreas y restos de plantas como maderas permineralizadas (familia Anacardiaceae), infiriendo que los sedimentos pertenecen a un ambiente cercano a una costa de mar tropical (Perrilliat et al., 2006; Juárez-Hernández, 2014; Pérez-Lara et al., 2017).

\section{Materiales y métodos}

La madera fósil fue preparada para su observación usando la técnica de lámina delgada, se obtuvieron cortes de los tres planos característicos: corte transversal, longitudinal tangencial y longi- tudinal radial. Los promedios de las mediciones se determinaron contando 25 campos al azar de cada estructura, tomando el valor más pequeño y más grande para los rangos. Los resultados de las mediciones se presentan en la descripción como el valor medio seguido del rango entre paréntesis. Para la terminología usada en la descripción, se siguió la propuesta del IAWA (International Association of Wood Anatomists) List of Microscopic Features for Hardwood Identification (IAWA Committee, 1989), y para la clasificación de las punteaduras vaso-radios se siguió la propuesta de Richter (1981). Las afinidades fueron determinadas consultando bibliografía especializada sobre el tema (e.g., Metcalfe y Chalk, 1950; Détienne y Jacquet, 1983; Ilic, 1987, 1991), además se realizó una búsqueda exhaustiva en InsideWood, una base de datos en línea para la identificación de maderas fósiles y actuales (InsideWood 2004-en adelante; Wheeler, 2011), los caracteres presentes se muestran con una p en cada número y en orden e.g. 13p, 22p, 25p, 31p, etc. Para la toma de fotografías de los caracteres anatómicos de la madera

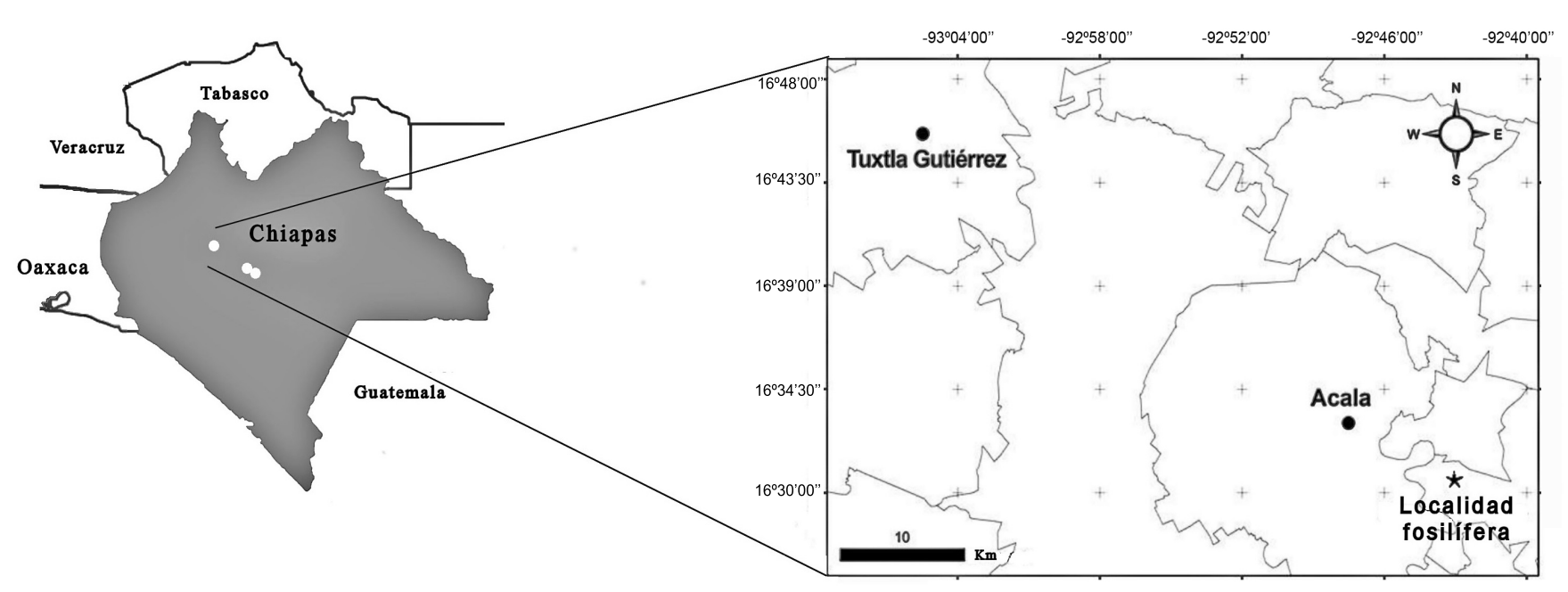




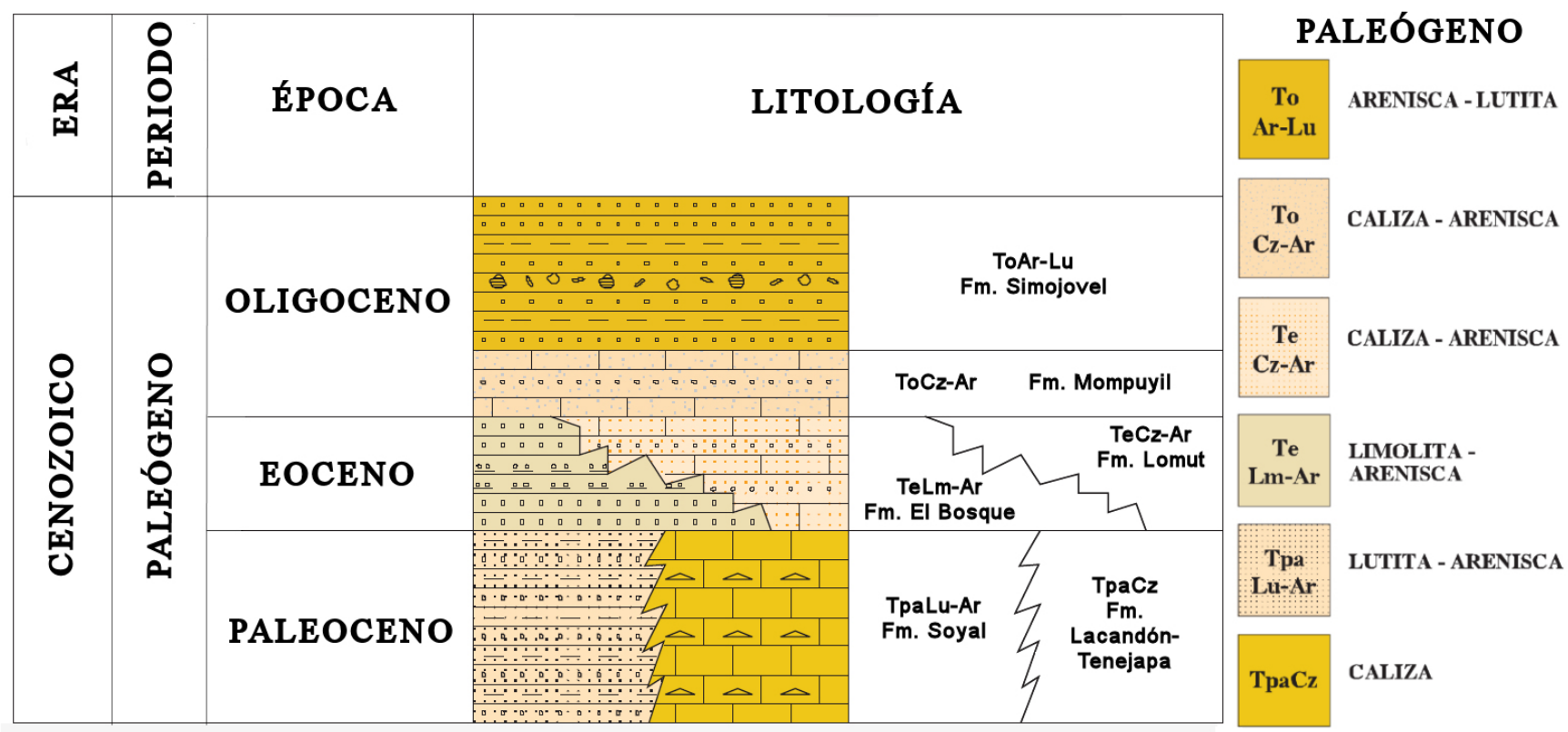

Figura 2 Secuencia estratigráfica de la Formación El Bosque (Modificado del Servicio Geológico Mexicano, 2005).

fósil se utilizó un microscopio óptico Olympus BX53 con una cámara digital SG100 con sensor CMOS de 10.5 Mpix y un microscopio Axio Cam MRc de Zeiss.

El material fósil descrito para este trabajo está resguardado en la Colección de Paleobotánica de la Escuela Nacional de Ciencias Biológicas del Instituto Politécnico Nacional. La madera fósil está precedida por la abreviatura IPN-PAL 05. Para cada lámina delgada se le asignó un número, e.g. IPN-PAL 05-L1, L2 etc., los mismos que se utilizaron para ilustrar las fotografias en cada pie de figura. Para su clasificación taxonómica se siguió al APG IV (Angiosperm Phylogeny Group, 2016).

\section{Resultados}

Familia: Lauraceae Juss.

Género: Laurinoxylon Felix emend. Dupéron, Dupéron-Laudoueneix, Sakala et De Franceschi

Especie: Laurinoxylon acalensis Pérez-Lara, Estrada-Ruiz et Castañeda-Posadas sp. nov.

Etimología: El epíteto específico hace alusión al municipio de Acala, Chiapas, de donde se recolectó el ejemplar fósil.
Edad: Eoceno.

Holotipo: IPN-PAL 05

Material: La descripción está basada en una sola muestra de madera permineralizada que mide alrededor de $9.7 \mathrm{~cm}$. de ancho y $15.7 \mathrm{~cm}$. de largo.

Diagnosis específica: anillos de crecimientos ausentes, porosidad difusa, vasos solitarios y en múltiples radiales de dos a tres, placas de perforación simples, punteaduras intervasculares alternas y poligonales, fibras septadas y no septadas, punteaduras vaso-radio con bordes reducidos de forma redonda, alargadas horizontal, vertical y diagonalmente, tílides común, parénquima axial paratraqueal, vasicéntrico y apotraqueal difuso, radios heterocelulares, células oleíferas asociadas entre las fibras y rara vez en los márgenes de los radios.

Descripción con los números de las características de IAWA: $2 p$ 5 13p 22p 23p 25p 32p 42p 47p 53p 56p 65p 66p 79p 97p 107p 108p $115 \mathrm{p} 124 \mathrm{p} 126 \mathrm{p}$

Descripción: Anillos de crecimiento ausentes, porosidad difusa, elementos de vasos solitarios y de 

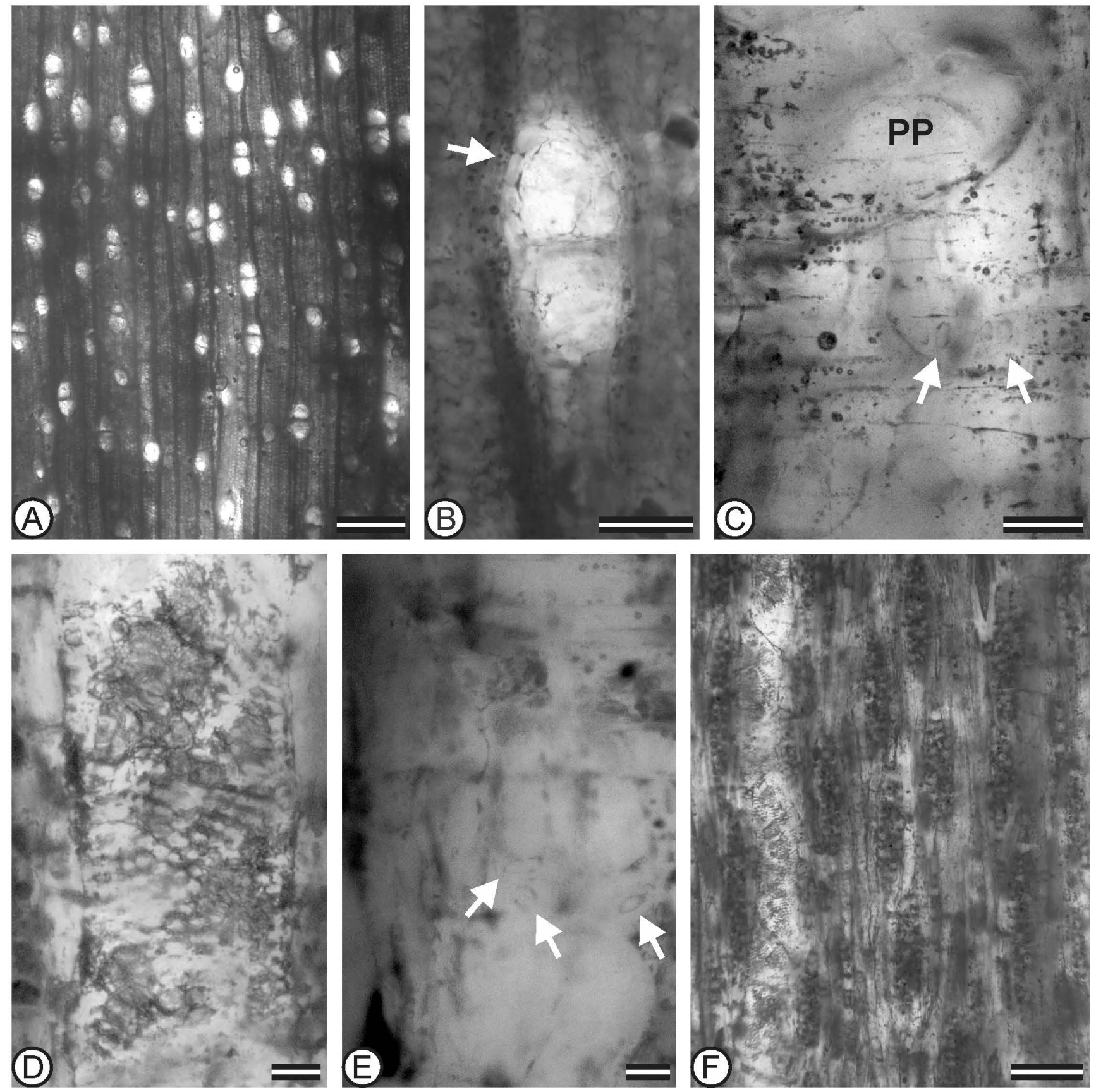

Figura 3 Laurinoxylon acalensis Pérez-Lara, Estrada-Ruiz et Castañeda-Posadas sp. nov. (IPN-PAL 05). $\urcorner$ - A: Mostrando la porosidad difusa, sin anillos de crecimiento (ST). Escala $=500 \mu \mathrm{m}$. - B: Parénquima vasicéntrico (flecha) y tílides (ST). Escala $=100 \mu \mathrm{m} . \quad-$ C: Placa de perforación simple (PP) y punteaduras vaso-radio con bordes reducidos alargadas verticalmente (flechas) (SR). Escala 50 um. - D: Acercamiento de las punteaduras intervasculares alternas con forma poligonal (STL). Escala $=25$ um. - E: Punteaduras vaso-radio con bordes reducidos, redondas a alargadas (flechas) (SR). Escala $=20 \mu \mathrm{m}$. - F: Elemento de vaso con tilides y radios uniseriados y multiseriados (STL). Escala $=100 \mu \mathrm{m}$.

ST = Sección transversal. - STL = Sección tangencial. - SR = Sección radial. 
2 a 3 vasos por múltiplo radial (Figuras $3 \mathrm{~A}$ y 3B); $50 \%$ corresponde a vasos solitarios, con forma circular a oval, con una frecuencia de 8 (4-10) por milímetro cuadrado (Figura 3A).

Los vasos presentan un diámetro tangencial de $160(110-212) \mu \mathrm{m}$, con un espesor de la pared de $12(6-15) \mu \mathrm{m}$. Placas de perforación simple con una inclinación de $65^{\circ}$ respecto al plano horizontal (Figura 3C). Punteaduras intervasculares alternas que miden 5 (4-6) $\mu \mathrm{m}$ de largo (Figura 3D). Las punteaduras vaso-radio con bordes reducidos de forma redondas, alargadas horizontal, vertical y diagonalmente (Clase b según Richter), presentan una longitud de 13.8 (9-20) $\mu \mathrm{m}$ (Figuras 3C y 3E). Los elementos de vasos presentan una longitud de 494 (341-646) $\mu \mathrm{m}$ (Figuras 3D y 3F). Presencia de tílides con forma de burbujas (Figuras 3B, 3D y $3 \mathrm{~F})$.

Radios uniseriados con 21 (14-28) $\mu \mathrm{m}$ de ancho, con 10 (7-14) células y 369 (358-411) $\mu \mathrm{m}$ de alto (Figura 3F). Radios multiseriados con $3(2-4)$ células, y 60 (37-74) $\mu \mathrm{m}$ de ancho, con 15 (7-27) células y 496 (314-812) um de alto (Figuras 3F, 4A a 4C), con una frecuencia de 8 (4-8) radios por milímetro, de éstos, el $20 \%$ son de una células de ancho, $60 \%$ de 2 células, $20 \%$ con 3 células. Extensiones uniseriadas conformadas principalmente de dos células de largo y muy raramente hasta con 4 células (Figura 4G). Radios heterocelulares con células procumbentes en el centro y usualmente con una a dos (1-4) hileras marginales de células cuadradas a erectas (Figuras $4 \mathrm{G}$ y $4 \mathrm{H}$ ).

Parénquima axial paratraqueal, vasicéntrico y apotraqueal escaso (Figura 3B).

Fibras septadas y no septadas (Figuras 4B y 4C). Distribuidas uniformemente con una longitud de 506 (452-581) $\mu \mathrm{m}$, un diámetro de 22 (14-34) $\mu \mathrm{m}$, y una pared de $4(2-9) \mu \mathrm{m}$.

Presencia de células oleíferas con forma alargada, se encuentran principalmente entre las fibras, muy rara vez asociados a los márgenes de los radios, con una longitud de 248 (130-446) $\mu$ m y 53 (3979) $\mu \mathrm{m}$ de ancho (Figuras $4 \mathrm{D}$ a $4 \mathrm{G}$ ). Las células oleíferas que se encuentran en los márgenes de los radios fueron observadas únicamente en corte tangencial (Figura 4G), en el plano radial no se encontraron.

\section{Discusión}

La presencia de células oleíferas o mucilaginosas en la madera de Chiapas está restringida a las familias Lauraceae, Annonaceae, Canellaceae, Hernandiaceae y Magnoliaceae (Metcalfe y Chalk, 1950; Carlquist, 2001). Sin embargo, la combinación de caracteres presentes en la madera de la Formación El Bosque indica una afinidad con la familia Lauraceae. Los caracteres que relacionan nuestra madera con Lauraceae son presencia de porosidad difusa, vasos solitarios y en múltiples radiales, placas de perforación simple, punteaduras intervasculares alternas de tamaño mediano a largas con formas poligonales, punteaduras vaso-radio con bordes reducidos, con forma redondas, alargadas horizontal, vertical y diagonalmente, fibras septadas y no septadas, parénquima axial paratraqueal, vasicéntrico y apotraqueal escaso, radios heterocelulares e idioblastos, además esta combinación de caracteres se puede encontrar dentro del género-fósil Laurinoxylon (Mantzuoka et al., 2016). Sin embargo, la madera descrita en este trabajo presenta punteaduras vaso-radio con bordes reducidos, alargadas horizontal, vertical y diagonalmente (clase b de acuerdo con Richter), frecuencia de los vasos 4-10 por milímetro cuadrado, y el número de células marginales asociadas a los radios 1-4 apoyan la propuesta de una nueva especie dentro de este género. La búsqueda en InsideWood con las características antes mencionadas, nos lleva al género-fósil Laurinoxylon y Ulminium Unger, sin embargo, recientemente se propone al género-fósil Ulminium como sinónimo de Laurinoxylon (Doweld, 2017).

\subsection{GOMPARACIÓN GON MADERAS DE LAURINOXYLON TIPO 2B}

Basados en la distribución de los idioblastos, Mantzuoka et al. (2016) reconocen 4 grupos dentro de Laurinoxylon: El tipo 1 - con idioblastos asociados únicamente a los radios, tipo $2 \mathrm{a}-\mathrm{con}$ idioblastos asociados tanto a los radios como al parénquima axial, tipo $2 \mathrm{~b}$ - con idioblastos asociados a los radios y entre las fibras, y el tipo 3- 

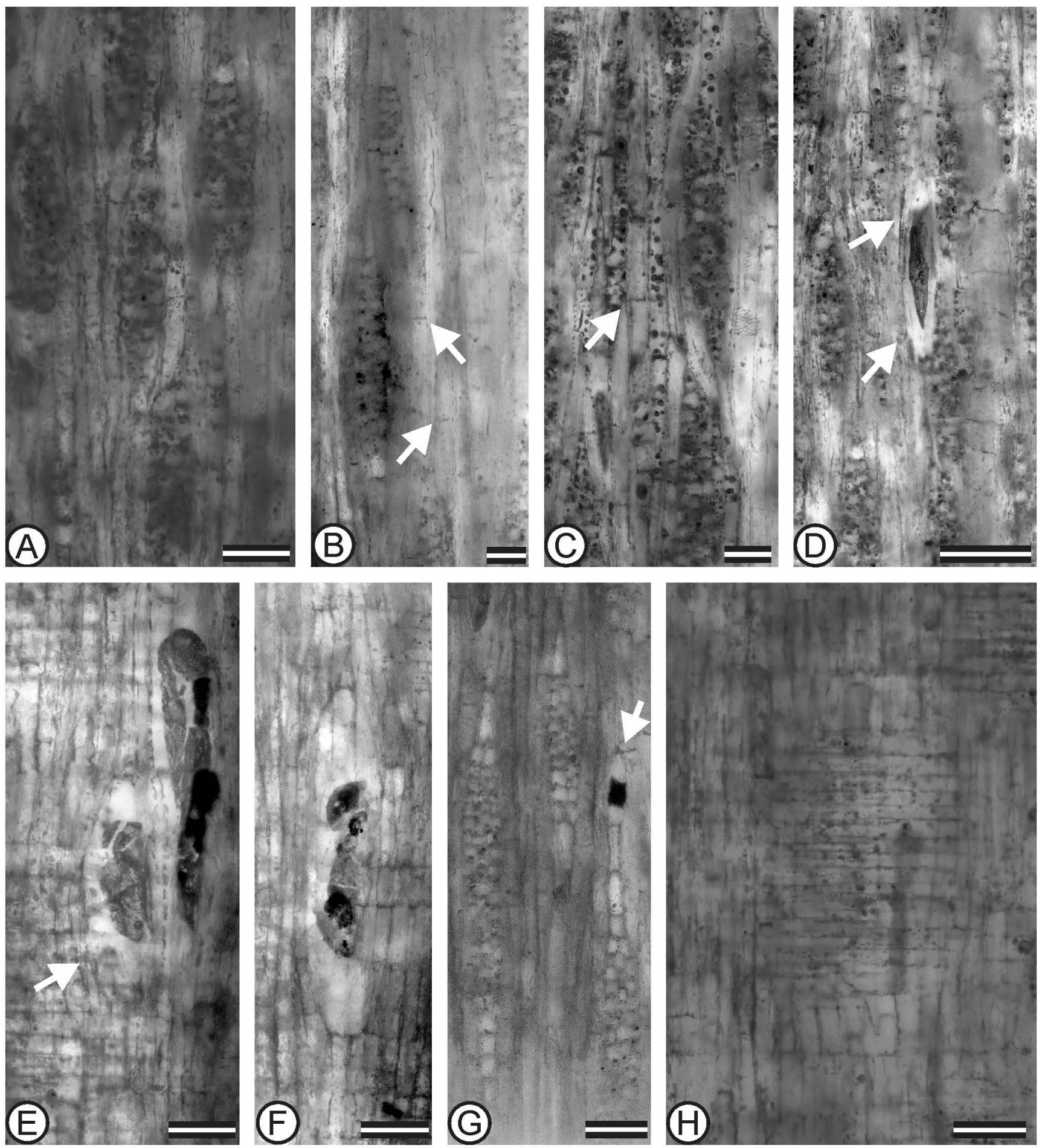

Figura 4 Laurinoxylon acalensis Pérez-Lara, Estrada-Ruiz et Castañeda-Posadas sp. nov. (IPN-PAL 05).

A: Radios triseriados y parénquima axial (STL). Escala $=100 \mu \mathrm{m} .-$ B: Fibras septadas (flechas). Escala $=65 \mu \mathrm{m}$. $-\mathrm{C}$ : Mostrando parénquima axial (flecha). Escala $=80 \mu \mathrm{m} .-\mathrm{D}$ : Mostrando una célula oleífera de forma elipsoidal con contenido obscuro (flechas) (STL). Escala $=193.5 \mu \mathrm{m}$. $-\mathrm{E}$ : mostrando otra célula oleífera entre las fibras (flecha) (SR). Escala $=66 \mu \mathrm{m}$. - F: Célula oleífera de forma alargada verticalmente (STL). Escala $=80 \mu \mathrm{m} .-\mathrm{G}$ : Célula oleífera en la cola de un radio (flecha) (STL). Escala $=100 \mu \mathrm{m} .-\mathrm{H}$ : Radios heterogéneos (SR). Escala $=100 \mu \mathrm{m}$. 
con idioblastos asociados a los radios, parénquima axial y entre las fibras. Siguiendo esta propuesta, nuestra madera corresponde al grupo $2 \mathrm{~b}$ (idioblastos en los radios y entre las fibras), donde se encuentran $L$. diluviale, y algunas otras especies que Mantzuoka et al. (2016) no discuten en su trabajo (e.g., por la edad, localidad o carencia de una descripción detallada) sin embargo, estos autores establecen que deberían ser asignadas a este grupo como: Laurinoxylon deomaliensis Lakhanpal, Prakash et Awasthi, este registro difiere de la madera de la Formación El Bosque por presentar anillos de crecimiento distinguibles, punteaduras intervasculares grandes, y radios heterocelulares con una hilera de células cuadradas (Lakhanpal et al., 1978). Laurinoxylon naginimariense Awasthi et Mehrota presenta características que difieren con nuestra madera por presentar punteaduras intervasculares diminutas, parénquima axial aliforme y confluente, radios con más de 4 células de ancho (Awasthi y Mehrotra, 1989). Laurinoxylon siwalicus Prasad se diferencia con $L$. acalensis por presentar punteaduras intervasculares grandes, radios grandes con más de 4 células de ancho, así como la presencia de radios heterocelulares con una sola hilera de células cuadradas (Prasad, 1989). Laurinoxylon varkalaensis Awasthi et Ahuja presenta punteaduras en las fibras, elementos de vasos menores a 350 $\mu \mathrm{m}$ de longitud, características no encontradas en L. acalensis (Awasthi y Ahuja, 1982). Finalmente, L. chalatenangensis Cevallos-Ferriz, Cerón-López et Flores-Rocha descrita para la Formación Chalatenango (Mioceno), de El Salvador, presenta una combinación no encontrada en nuestra madera como porosidad semicircular, anillos de crecimiento distinguibles, placas de perforación simples y escalariformes y radios heterogéneos con solo una hilera de células cuadradas (CevallosFerriz et al., 2016). Para el Mioceno-Plioceno de la India se describe Laurinoxylon deccanensis Bande et Prakash que a diferencia de nuestra madera no presenta tílides y los radios van de 4-10 células de ancho (Bande y Prakash, 1980). Süss (1958) para el Oligoceno de Alemania reporta la presencia de Laurinoxylon microtracheale Süss que a diferencia de nuestra madera las punteaduras vaso-radio son similares a las intervasculares, presenta punteaduras en las fibras y el ancho de los radios es mayor (4-10). Los géneros actuales con anatomía similar a la descrita para el tipo 2b de Laurinoxylon son Actinodaphne Nees, Nectandra Rol. ex Rottb. y Neolitsea (Benth. et Hook.f.) Merr (Tabla 1). De los cuales Nectandra crece exclusivamente en el centro y sur de América, mientras que Actinodaphne y Neolitsea tienen una amplia distribución en Asia.

\subsection{GOMPARAGIÓN GON MADERAS EOGÉNIGAS}

Se han descrito aproximadamente 12 especies de maderas pertenecientes a Laurinoxylon del Eoceno en todo el mundo (InsideWood 2004-en adelante). Sin embargo, Mantzouka et al. (2016) excluyen a varias especies del género-fósil Laurinoxylon como L. limagnense Privé-Gill et Pelletier, L. annularis Gottwald, L. compressum Huard, L. seemannianum Mädel y $L$. atlanticum (Romero) DupéronLaudoueneix et Dupéron, esto debido a que las maderas antes mencionadas presentan características como porosidad circular, bandas de parénquima y células oleíferas asociadas únicamente a los radios y que no son afines a las encontradas en Laurinoxylon, por lo cual quedan descartadas. Gottwald (1992) reporta la presencia de L. litseoides Suss en Helmstedt, Alemania, la cual difiere de la madera de la Formación El Bosque por la presencia de anillos de crecimiento distinguibles, existencia de idioblastos más pequeños (37-105 $\mu \mathrm{m})$ así como punteaduras intervasculares de mayor tamaño $(6-7.5 \mu \mathrm{m})$. Recientemente, Jud y Dunham (2017) en la Península de Azuero en Panamá, describen a L. elongatum Jud, esta especie difiere de la madera de la Formación El Bosque por la presencia de placas de perforación simples y escalariformes, ausencia de parénquima vasicéntrico, y células oleíferas asociadas únicamente a los radios. Laurinoxylon wheelerae (Crawley) DupéronLaudoueneix et Dupéron difiere por presentar únicamente una hilera de células erectas en los radios, parénquima axial aliforme y confluente, y punteaduras en las fibras (Crawley, 1989). 
Tabla 1. Comparación de Laurinoxylon acalensis (en negrita) con otras especies de Laurinoxylon y con los géneros actuales a los que se relaciona el grupo $2 \mathrm{~b}$.

\begin{tabular}{|c|c|c|c|c|c|c|c|c|c|}
\hline Taxón & $\mathbf{A C}$ & $\mathbf{A V}$ & Fibras & PP & P. axial & Radios & idioblastos & $\begin{array}{c}\text { Punteaduras } \\
\text { intervasculares } \\
\text { en } \mu \mathrm{m}\end{array}$ & $\begin{array}{l}\text { Punteaduras } \\
\text { vaso-radio }\end{array}$ \\
\hline Actinodaphne Nees & Ind/dis & $\mathrm{S}$ & $\mathrm{S}, \mathrm{NS}$ & S-E & $\mathrm{D}, \mathrm{V}, \mathrm{C}$ & He 2-4 & R, PA y F & A (4-7) & B \\
\hline Nectandra Rol. ex Rottb & Ind/dis & $\mathrm{S}, \mathrm{MR}$ & $\mathrm{S}$ & S, S-E & P-e, V & $\mathrm{He}$ & $\mathrm{R}, \mathrm{PA}$ y $\mathrm{F}$ & A $(9-14)$ & B \\
\hline $\begin{array}{l}\text { Neolitsea (Benth. et Hook.f.) } \\
\text { Merr }\end{array}$ & Ind/dis & $\mathrm{S}, \mathrm{MR}$ & $\mathrm{S}, \mathrm{NS}$ & S-E & $\begin{array}{l}\mathrm{D}, \mathrm{E}, \mathrm{V}, \\
\quad \mathrm{A}, \mathrm{C}\end{array}$ & He 1-4 & R, PA y F & A (4-10) & B \\
\hline $\begin{array}{l}\text { Laurinoxylon Felix emend. } \\
\text { Dupéron, Dupéron-Laudoueneix, } \\
\text { Sakala et De Franceschi }\end{array}$ & Ind/dis & $\mathrm{S}, \mathrm{MR}$ & $\mathrm{S}, \mathrm{NS}$ & S, S-E & $\mathrm{P}$ & He $2-4$ & $\begin{array}{c}\text { R, RAP, } \\
\text { RF, RAPF }\end{array}$ & A $(6-10)$ & $\begin{array}{l}\text { Largas y } \\
\text { estiradas }\end{array}$ \\
\hline $\begin{array}{l}\text { L. acalensis Pérez-Lara, Estrada- } \\
\text { Ruiz et Castañeda-Posadas }\end{array}$ & Ind & S, MR & $\mathbf{S}, \mathbf{N S}$ & $\mathbf{S}$ & $\mathbf{P}, \mathbf{V}$ & He 2-4 & RF & A (4-6) & $\mathbf{B}$ \\
\hline
\end{tabular}

Anillos de crecimiento (AC), presentes (dis), ausentes (ind); Agrupamiento de los vasos (AV); Fibras septadas (S), no septadas (NS); Placas de perforación (PP) simples (S) o escalariformes (E); Parénquima axial (P. axial) Difuso (D), Vasicéntrico (V), Confluente (C), Paratraqueal escaso (P-e), escaso (E), Aliforme (A), paratraqueal ( $p$ ); Idioblastos asociados a los radios (R), Asociados al parénquima axial (PA) y entre las fibras (F); Punteaduras intervasculares alternas (A); Punteaduras vaso-radio con bordes reducidos, alargadas horizontal, vertical y diagonalmente (B); Radios heterocelulares $(\mathrm{He})$.

Finalmente, Boonchai y Manchester (2012) describen L. stichkai N. Boonchai et Manchester para la Formación Bridger, Wyoming, Estados Unidos, la cual difiere con nuestra madera por presentar anillos de crecimiento débilmente desarrollados, radios con una sola hilera de células cuadradas, e idioblastos asociados a los radios y al parénquima axial.

\subsection{COMPARAGIÓN GON MADERAS FÓSILES DE LAURAGEAE DE MÉXICO}

En México, se han recolectado maderas y hojas relacionadas con Lauraceae en sedimentos del Cretácico Superior de las formaciones Olmos y San Carlos en el norte de México, así como dos registros de maderas del Mioceno de Tlaxcala y Chiapas (e.g., Weber, 1978; Castañeda-Posadas et al., 2009; Estrada-Ruiz et al., 2010; Flores-Rocha et al., 2013; García-Hernández et al., 2016). Relacionado con el estudio de la anatomía de madera se han descrito un total de 5 especies afines a esta familia. Para la Formación Olmos (Campaniano tardío), Coahuila se han descrito 2 maderas; la primera de ellas está relacionada al grupo Phyllanthoide/
Lauraceae la cual a diferencia de nuestra madera presenta radios heterocelulares con una o dos hileras de células erectas, la longitud y diámetro de los vasos es mucho menor $(150 \mu \mathrm{m}$ y $69 \mu \mathrm{m}$ respectivamente) y punteaduras intervasculares romboidales (Cevallos-Ferriz y Weber, 1992). Más tarde, Estrada-Ruiz et al. (2010) describen un nuevo género y especie para la familia, nombrándolo Olmosoxylon upchurchii Estrada-Ruiz, MartínezCabrera et Cevallos-Ferriz, la cual presenta células oleíferas asociadas únicamente a los radios, radios homocelulares y heterocelulares compuestos por una hilera de células cuadradas, y punteaduras intervasculares de mayor tamaño, siendo diferente de Laurinoxylon acalensis. Para la Formación San Carlos (Coniaciano-Maastrichtiano), Chihuahua se reporta la presencia de Paraphyllanthoxylon anasazi Wheeler, McClammer et LaPasha la cual difiere por tener radios heterocelulares con una hilera de células cuadradas, y la ausencia de células oleíferas (García-Hernández et al., 2016). Para el centro del país se ha descrito la presencia de Argapaloxylon richterii Castañeda-Posadas, Calvillo-Canadell et Cevallos-Ferriz en sedimentos miocénicos de la localidad La Mina, Tlaxcala, la cual presenta ani- 
llos de crecimiento delimitados por parénquima marginal, traqueidas vasicéntricas, punteaduras vaso-radio ovoides y opuestas, cristales en la fibras y radios homocelulares (Castañeda-Posadas et al., 2009), siendo claramente diferente de nuestra madera. Finalmente, para el Mioceno de Chiapas de describe una madera con afinidad a Lauraceae la cual a diferencia de nuestra madera presenta un porcentaje mayor de vasos solitarios $(80 \%)$, radios con una sola hilera de células erectas, cristales en las células marginales de los radios, y ausencia de parénquima vasicéntrico (Flores-Rocha et al., 2013).

Para la Formación El Bosque únicamente se ha reportado la presencia de una madera de Anacardiaceae (Pérez-Lara et al., 2017), siendo este el segundo registro con base en anatomía de madera para la Formación El Bosque y para el Eoceno de México. Anacardiaceae y Lauraceae crecen actualmente en regiones tropicales-templadas, que aunado con la presencia de fósiles de zonas costeras (e.g. gasterópodos, bivalvos, equinodermos, vertebras de tiburón, tortugas, algas calcáreas) sustentan aún más la propuesta de que durante esta época se desarrolló en la región un ambiente con características de climas tropicales.

\section{Conclusión}

En este trabajo se describe una nueva especie con base en una madera fósil con caracteres anatómicos que la relacionan a la familia Lauraceae y particularmente al género-fósil Laurinoxylon para el Eoceno de Chiapas. Siendo éste, el primer reporte formal del género-fósil para México, que aunado a los recientes trabajos paleobotánicos en Chiapas ayudará a tener una perspectiva regional sobre las comunidades de plantas presentes durante el Eoceno, y soporta aún más la teoría que durante el Cenozoico la familia Lauraceae tuvo una amplia distribución a lo largo del país. La presencia de este taxón en los sedimentos eocénicos de la Formación El Bosque comienzan a dar una idea sobre la prevalencia de una temperatura cálida para esa región, ya que las maderas de Lauraceae indican una temperatura relativamente cálida (Mai, 1995).

\section{Agradecimientos}

Agradecemos a Susana Guzmán del Instituto de Biología de la UNAM por su ayuda en la toma de fotografías. A los revisores anónimos por sus valiosos comentarios. Parte de esta investigación fue financiada por el CONACyT (240241) y el SIPIPN (20170872 y 20180026) otorgados a E.E.R y a los apoyos VIEP-BUAP, otorgados a C.C.P.

\section{Referencias}

Angiosperm Phylogeny Group (APG), 2016, An update of the Angiosperm Phylogeny Group classification for the orders and families of flowering plants: APG IV: Botanical Journal of the Linnean Society, 181, 1-20.

Awasthi, N., Ahuja, M., 1982, Investigations of some carbonised woods from the Neogene of Varkala in Kerala coast: Geophytology, 12, 245-259.

Awasthi, N., Mehrotra, R.C., 1989, Some fossil woods from Tipam sandstone of Assam and Nagaland: Palaeobotanist, 38, 277-284.

Bande, M.B., Prakash, U., 1980, Four new fossil dicotyledonous woods from the Deccan Intertrappean beds near Shahpura, Mandla District, M.P: Geophytology, 10, 268-271.

Boonchai, N., Manchester, S.R., 2012, Systematic Affinities of Early Eocene Petrified Woods from Big Sandy Reservoir, Southwestern Wyoming: International Journal of Plant Sciences, 173(2), 209-227. https://doi. org/10.1086/663161

Carlquist S., 2001, Comparative wood anatomy: Systematic, ecological, and evolutionary aspects of dicotyledon wood: Berlin, Heidelberg, Springer Verlag, 436 p. 
Castañeda-Posadas, C., Calvillo-Canadell, L., Cevallos-Ferriz, S.R.S., 2009, Woods from Miocene sediments in Panotla, Tlaxcala, Mexico: Review of Palaeobotany and Palynology, 156, 494-506. https://doi. org/10.1016/j.revpalbo.2009.04.013

Cevallos-Ferriz, S.R.S., Weber, R., 1992, Dicotyledonous wood from the upper Cretaceous (Maastrichtian) of Coahuila: Universidad Nacional Autónoma de México, Instituto de Geología, Revista, 10, 65-70.

Cevallos-Ferriz, S.R.S., López, G.C., FloresRocha, L.A., 2016, Laurinoxylon chalatenangensis sp. nov. from the Miocene Chalatenango Formation, El Salvador: Review of Palaeobotany and Palynology, 233, 186-192. https://doi.org/10.1016/j. revpalbo.2016.04.003

Crawley, M., 1989, Dicotyledonous wood from the Lower Tertiary of Britain: Palaeontology, 32, 597-622.

Détienne, P., Jacquet, P., 1983, Atlas d'identification des bois de l'Amazonie et des régions voisines: Nogent-sur-Marne, France, Centre Technique Forestier Tropical,. 640 p.

Doweld, A., 2017, (2533-2534) Proposals to conserve the name Laurinoxylon against Ulminium and to reject the name Laurinium (fossil Lauraceae): Taxon, 66 (3),764-765. https://doi.org/10.12705/663.32

Drinnan, A.N., Crane, P.R., Friis, E.M., Pedersen, K.R., 1990, Lauraceous flowers from the Potomac Group (mid-Cretaceous) of eastern North America: International Journal of Plant Sciences, 151(3), 370-384. https://doi. org/10.1086/337838

Dupéron, J., Dupéron-Laudoueneix, M., Sakala, J., De Franceschi, D., 2008, Ulminium diluviale Unger: historique de la découverte et nouvelle étude: Annales de Paléontologie, 94(1), 1-12. https://doi.org/10.1016/j. annpal.2007.12.003

Estrada-Ruiz, E., Martínez-Cabrera, H.I., Cevallos-Ferriz, S.R.S., 2010, Fossil wood from the Olmos Formation (late Campanianearly Maastrichtian) Coahuila, Mexico: American Journal of Botany, 97, 1179-1194.
Flores-Rocha, L.A., Cevallos-Ferriz, S.R.S., Calvillo-Canadell, L., Avendaño-Gil, M.J., 2013, Diversidad xilológica del mioceno de la localidad "Arroyo Maderas", Marqués de Comillas, Chiapas: Paleontología Mexicana, 63, 17-23.

García-Hernández, P., Estrada-Ruiz, E., MartínezCabrera, H.I., 2016, Maderas fósiles de la Formación San Carlos (Cretácico Superior), Chihuahua, México: Botanical Sciences, 94(2), 269-280. https://doi.org/10.17129/ botsci. 438

Gottwald, H., 1992, Hölzer aus Marinen Sanden des Oberen Eozän von Helmstedt (Niedersachsen): Palaeontographica, B 225, 27-103.

Gregory, M., Poole, I., Wheeler, E.A., 2009, Fossil dicot wood names. An annotated list with full bibliography: IAWA Journal, Suppl. 6, 220.

IAWA Committee (eds. Wheeler, E. A., Baas, P., Gasson, P. E.), 1989, IAWA list of microscopic features for hardwood identification: IAWA Bull, 10, 219-232.

Ilic, J., 1987, The CSIRO family key for hardwood identification: Australia, CSIRO. 171 p.

Ilic, J., 1991, CSIRO Atlas of hardwoods: Berlin,Springer-Verlag,. 525 p.

InsideWood, 2004-onwards, disponible en <http://insidewood.lib.ncsu.edu/search>, consultado en septiembre de 2017.

Johansson, J.T., 2013-onwards, The phylogeny of angiosperms, disponible en <http://angio. bergianska.se $>$, consultado en septiembre de 2017.

Juárez-Hernández, E., 2014， Análisis hidrogeoquímico de la cuenca del río grande Comitán: UNAM, México, Facultad de Ingeniería, Tesis de Licenciatura, 107 p.

Jud, N.A., Dunham, J.I., 2017, Fossil woods from the Cenozoic of Panama (Azuero Peninsula) reveal an ancient neotropical rainforest: IAWA Journal, 38(3), 366-411. https://doi. org/10.1163/22941932-20170176

Lakhanpal, R.N., Prakash, U., Awasthi N., 1978 (1981), Some more dicotyledonous woods from the Tertiary of Deomali, Arunachal Pradesh, India: The Palaeobotanist, 27, 232-252. 
Lorea-Hernández, F., 2002, La familia Lauraceae en el sur de México: Diversidad, distribución y estado de conservación: Boletín de la Sociedad Botánica de México, 71, 59-70.

Mai, D.H., 1995, Tertiäre Vegetationsgeschichte Europas: Jena, Germany, Gustav Fisher Verlag, $691 \mathrm{p}$.

Mantzouka, D., Karakitsios,V., Sakala, J., Wheeler, E.A., 2016, Using idioblasts to group Laurinoxylon species - Case study from the Oligo-Miocene of Europe: IAWA Journal, 37(3), 459-488. https://doi. org/10.1163/22941932-20160147

Metcalfe, G.R., Chalk, L., 1950, Anatomy of the Dicotyledons. 2 Vols: Oxford, U.K., Clarendon Press. 724 p.

Pérez-Lara, D.K., Castañeda-Posadas, C., Estrada-Ruiz, E., 2017, A new genus of Anacardiaceae from El Bosque Formation (Eocene), Chiapas, Mexico: IAWA Journal, 38(4), 543-552. https://doi. org/10.1163/22941932-20170179

Perrilliat, M.C., Avendaño, J., Vega, FJ., Solé, J., 2006, Lower Eocene Gastropods from El Bosque Formation, Central Chiapas, Mexico: The Veliger, 48, 3, 37-55.

Poole, I., Richter, H.G., Francis, J.E., 2000, Evidence for Gondwanan origins for Sassafras (Lauraceae)? Late Cretaceous fossil wood of Antarctica: IAWA Journal, 21(4), 463-75. https://doi. org/10.1163/22941932-90000262

Prasad, M., 1989, Occurrence of a lauraceous wood in the Siwalik sediments, India: Geophytology, 19(2), 191-192.

Richter, H.G., 1981, Anantomie des sekündaren Xylems und der Rinde der Lauraceae: Sonderbände des Naturwissenschaftlichen Vereins in Hamburg, 5, Verlag Paul Parey, Hamburgo, 148 p.
Rohwer, J.G., 1993, Lauraceae. In The Families and Genera of Vascular Plants. Volume II. Flowering Plants - Dicotyledons. Magnoliid, Hamamelid and Caryophyllid Families (eds K. Kubitzki, J.G. Rohwer \& V. Bittrich) Berlin, Heidelberg, New York: SpringerVerlag, 366-91.

Süss, H., 1958, Anatomische Untersuchungen über die Lorbeerhölzer aus dem Tertiär des Hasenberges bei Wiesa in Sachsen: Abhandlungen Der Deutschen Akademie Der Wissenschaften Zu Berlin Jahrbuch, 8, $1-59$.

Upchurch, G. R., Dilcher, D. L., 1990, Cenomanian angiosperm leaf megafossils, Dakota Formation, Rose Creek Locality, Jefferson County, southeastern Nebraska: US Geological Survey Bulletin, 1915, 1-55. https://doi.org/10.3133/b1915

van der Werff, H., 1997, Flora del Bajío y de regiones adyacentes. Familia Lauraceae: Fascículo 56, 1-58.

von Balthazar, M., Pedersen, K.R., Crane, P.R., Friis, E.M., 2007, Potomacanthus lobatus gen. et sp. nov., a new flower of probable Lauraceae from the Early Cretaceous (Early to Middle Albian) of eastern North America: American Journal of Botany, 94(12), 204153. https://doi.org/10.3732/ajb.94.12.2041

Weber, R., 1978, Some aspects of the Upper Cretaceous angiosperm flora of Coahuila, Mexico: Cour. Forsch.-Inst. Senckenberg, 30, 38-46.

Wheeler, E.A., 2011, InsideWood: a web resource for hardwood anatomy: IAWA Journal, 32(2), 199-211. https://doi. org/10.1163/22941932-90000051

Wheeler, E.A., Manchester, S., 2002, Woods of the Middle Eocene Nut Beds Flora, Clarno Formation, Oregon, USA: IAWA Journal, Suppl. 3, 188. 